\title{
The moisture condition of the brick walls in the basements of a medieval monastery
}

\author{
Anna Hoła, ${ }^{*}$ \\ Wroclaw University of Science and Technology, Faculty of Civil Engineering, Poland
}

\begin{abstract}
The paper presents the moisture condition of the brick walls in the basements of a monastery that was built at the turn of the 13th and 14th centuries in Pomerania in Poland. The provided results of the research, the reasons for the moisture and the method of assuring damp-proof protection are a starting point for further renovation and restoration works that aim to restore the utilitarian function of the basements.
\end{abstract}

\section{Introduction}

The problem of excessive moisture concerns most historic buildings with brick walls. It is the result of direct long-term contact of a wall with the ground, caused by the lack of horizontal and vertical damp insulation that was not used in the past. The consequence of this state is the gradual penetration into the wall of water contained in the ground and the salts that are dissolved in it. As a result of the capillary process, this moisture moves into higher and higher parts of the wall, while at the same time dampening and salting it. Bricks and mortar are then damaged and this in turn causes, among others, a reduction of the safety of a structure, a reduction of the thermal insulation of a building's external partitions, as well as the deterioration of the operating conditions in rooms $[1,2,3]$.

In order to stop the destructive processes caused by excessive moisture, it is necessary to determine the level of advancement and the causes for excessive moisture and salinity of walls before the renovation of a historic building, without which it is not possible to design appropriate anti-moisture or water protections $[4,5,6]$.

The article presents the results of tests of the moisture content of brick walls in the basements of a monastery, which is a part of a church and monastery complex dated from the turn of the thirteenth and fourteenth century. According to [7], this object was erected according to the classical scheme of the Cistercian monastery, which is based on a square of buildings gathered around a patio and surrounded by cloisters. In the 19th century the monastery was partially rebuilt and regatized. Parts that have survived to this day in an unchanged condition include the bigger part of the northern wing, which has basement rooms located underground.

Two of the above-mentioned basement rooms have walls made of solid ceramic brick with lime mortar. The thicknesses of these walls vary and are in a range of about $60 \mathrm{~cm}$ to about $180 \mathrm{~cm}$. Above the larger cellars there is a cross vault with ribs, supported on the

\footnotetext{
*Corresponding author: anna.hola@pwr.edu.pl
} 
centraı pııar and walıs ( $\mathrm{r} 1 \mathrm{~g}$. I a), wnıe tne smanter cenlar nas a barreı vauı (Fig. ID). I nere is a cement floor in the larger basement (originally there was a brick floor) that was made in around 1985, while there is no floor in the smaller basement room.

Due to the large historical value of the building, a restoration of the utility function of the basements is planned. However, in the present state it is impossible due to the visible significant moisture of the walls, large fragments of which are covered with mould.
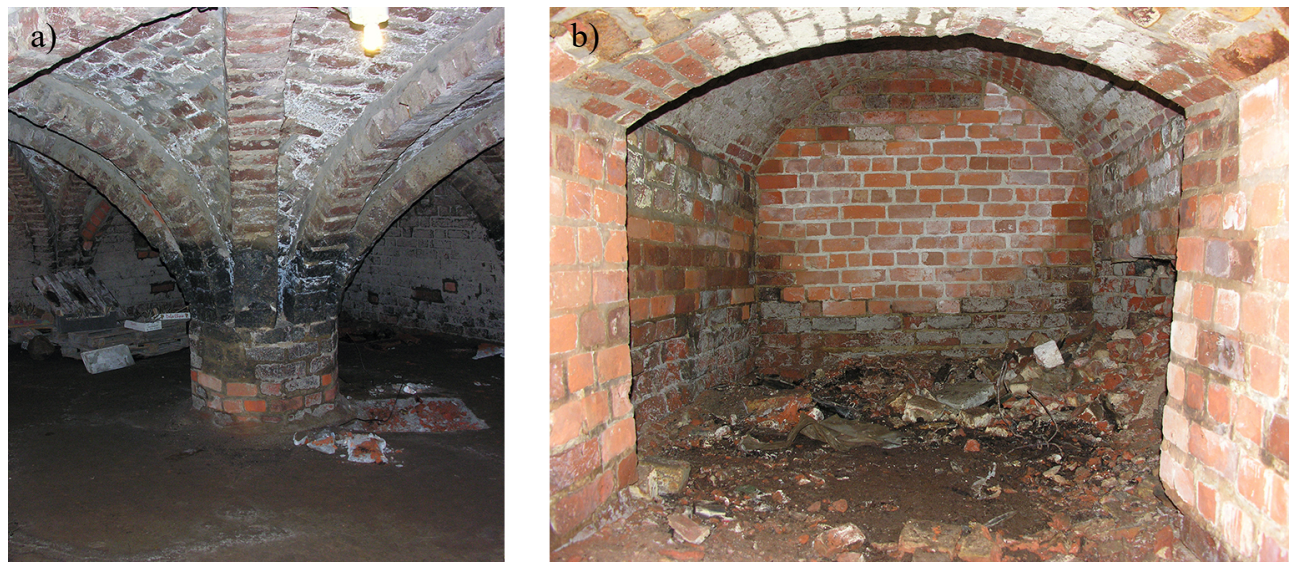

Fig. 1. View of basement rooms under the northern wing of the monastery

\section{Description of the carried out tests}

Tests of the moisture content of the brick walls of the monastery's basements were carried out using non-destructive dielectric and destructive gravimetric methods $[8,9,10]$. Due to the poor technical condition of the basement walls, conservation services agreed to interfere with the structure of the historical walls to the extent that is necessary to obtain the most reliable test results.

Non-destructive tests of the mass moisture content $U_{m}$ were carried out using a method that is based on measurements of the dielectric properties of a material. These measurements were made using a GANN UNI 2 meter with an active B50 ball probe, which allows the average degree of the moisture content of a building's partitions to be determined to a depth of about $10 \mathrm{~cm}$ from their surface. The meter was scaled on specimens that were taken from a wall, the moisture content of which was determined using the gravimetric method in laboratory conditions. The number of collected specimens allowed several dozen pairs of results (unitless $\mathrm{X}$ indications of the meter and the mass moisture content $U_{m}$ determined using the gravimetric method) to be created, which in turn enabled the exact correlative dependency that is representative for the used meter and the tested wall to be determined. This dependence is described by the following exponential mathematical function:

where :

$$
U_{m}=0,1665 \mathrm{e}^{0,035 X}
$$

$U_{m}$ - mass moisture content,

$X$ - unitless indications of a meter.

The determination coefficient of $R^{2}=0,8362$ was obtained, which proves that this dependency was well correlated to the results obtained from the conducted research. 
Measurements of the moisture content of brick walls with the use of a GANN UNI 2 meter were carried out in both basement rooms at several heights starting from the floor/ground level. This allowed the mass moisture content $U_{m}$ distribution along the wall's height $h$ to be determined. Due to the fact that walls in historical buildings are often even damp to a few meters above the level on which they have direct contact with the ground, in order to determine how high the walls are moist in the tested object, the moisture content measurements were also carried out in the ground level of the refectory and the cloisters located directly above the basement.

The distribution of mass moisture content $U_{m}$ along the wall thickness $d$, both in the underground and ground level, was experimentally determined using the gravimetric method. Moreover, a qualitative and semi-quantitative analysis of brick and mortar specimens were carried out and the types and concentrations of salts (chlorides, sulphates and nitrates) contained in the walls were determined [11].

By making an excavation in the underground floor, it was found that the level of the groundwater table is about $20 \mathrm{~cm}$ below the upper surface of the floor. This level is stabilized due to the fact that there is drainage around the object, which was made in the past and is still functioning.

\section{Test results and their analysis}

When analysing the results of the measurements (carried out using the non-destructive dielectric method and destructive gravimetric method) of the mass moisture content of the brick walls in the medieval monastery, it was found that according to the moisture classification, which is assumed in technical literature [4-5, 12-13], the tested brick walls are wet on their entire height. This is because their mass moisture content exceeds $12.0 \%$.

The average values of this moisture content $\bar{U}_{m}$ in the subsurface zone at the height of $20 \mathrm{~cm}, 100 \mathrm{~cm}$ and $180 \mathrm{~cm}$ above the floor level are equal to about $21.0 \%, 19.0 \%$ and $15.0 \%$ (Fig. 2a) respectively. The same applies to the brick pillar and the vault that is based on it. In the subsurface area, the average mass moisture content values of the wall are equal to about $23.0 \%$ at a height of $5 \mathrm{~cm}$ above the floor level, over $14.0 \%$ at a height of $25 \mathrm{~cm}$ above the floor level, less than $17.0 \%$ at a height of $50 \mathrm{~cm}$ above the floor, over $14.0 \%$ at a height of $100 \mathrm{~cm}$ above the floor level and over $15 \%$ at heights of $150 \mathrm{~cm}$ and $190 \mathrm{~cm}$ above the floor level. This condition is illustrated in Figure $2 b$.

The conducted tests also show that the mass moisture content $U_{m}$ across the thickness $d$ of both the wall and the pillar is higher than that found in the subsurface zone. Tests carried out in one of the external walls of the underground level at a height of $20 \mathrm{~cm}$ above the floor showed that the moisture content is close to $22.0 \%$ in the subsurface zone, about $27.0 \%$ at a depth of $40 \mathrm{~cm}$ and to about $32.0 \%$ at a depth of $80 \mathrm{~cm}$ - i.e. in the middle of the wall's thickness (Fig. 3). In the case of the pillar, the results are as follows: $14.0 \%$ in the subsurface zone, $25.0 \%$ at a depth of $26 \mathrm{~cm}$ and $28.0 \%$ at a depth of $50 \mathrm{~cm}-$ i.e. in the middle of the pillar's thickness.

In turn, when analysing the results of the measurements of the mass moisture content of the basement's brick walls, which were primarily carried out using the dielectric method and additionally using the gravimetric method on internal and external wall surfaces and inside the thicknesses of these walls, it was found that the moisture content of these walls is clearly differentiated around the circumference. The averaged values of this moisture content in the subsurface zone, which were obtained from the interior of the rooms at heights of $15 \mathrm{~cm}, 50 \mathrm{~cm}$ and $100 \mathrm{~cm}$ above the floor level in the refectory, are respectively about $11.0 \%$, over $8.0 \%$ and around $4.5 \%$ (Fig. $2 \mathrm{a}$ ). This means that in the zone adjacent to the floor, the tested walls are highly damp, while at the height of about $100 \mathrm{~cm}$, they are characterized by an elevated moisture level. 
which were measured on the external side of the walls at heights of $30 \mathrm{~cm}, 60 \mathrm{~cm}, 90 \mathrm{~cm}$ and $120 \mathrm{~cm}$ above the ground level are equal to $4.0 \%$, over $3.0 \%, 3.0 \%$ and nearly $2.5 \%$, respectively. In other words, these walls have an elevated moisture content level in the zone up to a height of about $60 \mathrm{~cm}$ from the ground level. These facts indicate that in the case of the tested walls, the capillary action of water from below the ground level is dominant, while the lateral capillary action of water from the ground has a lower impact on their moisture status.

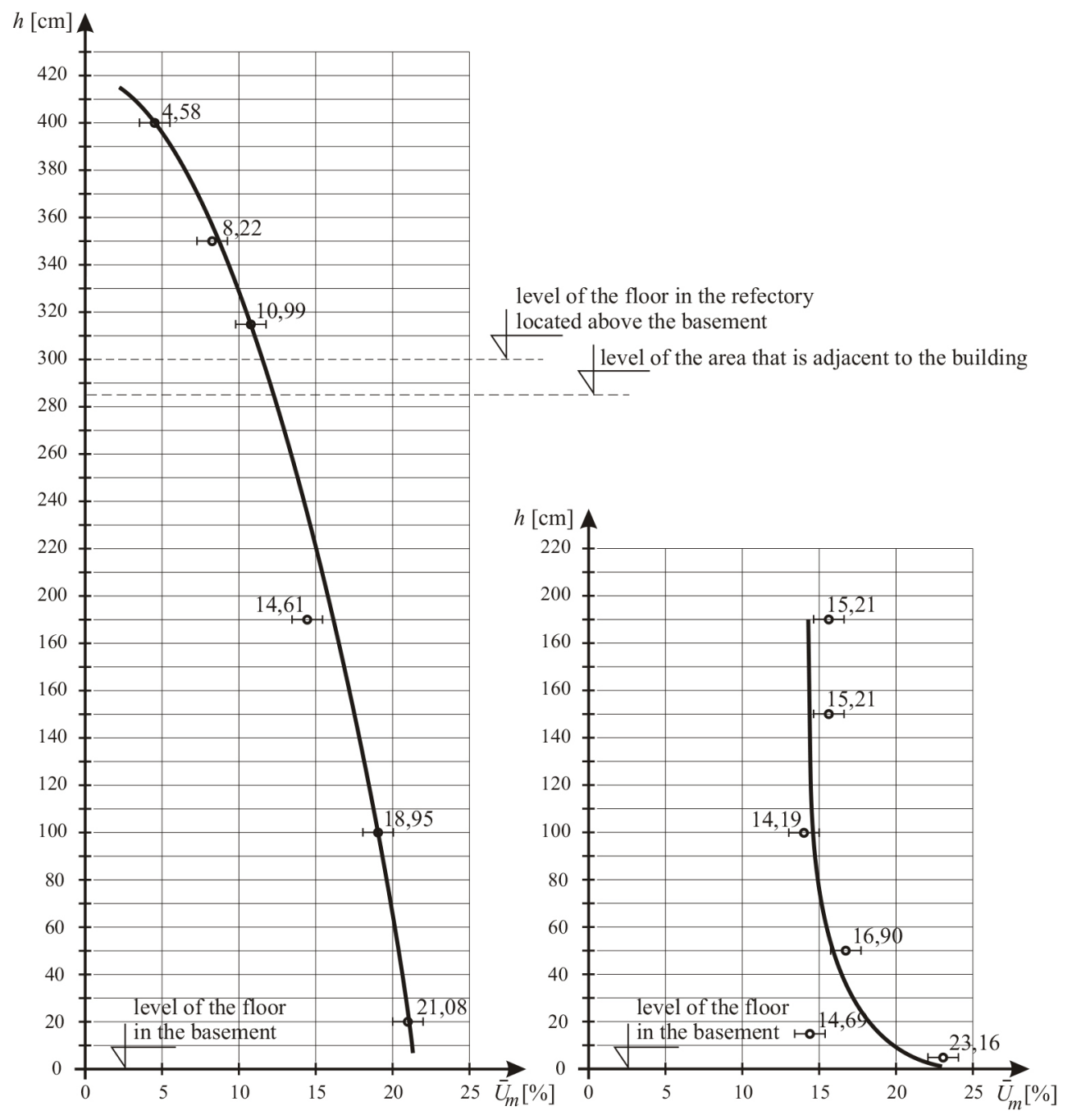

Fig. 2. Average distributions of mass moisture content $U_{m}$ of the underground walls in the subsurface zone of a wall: a) at the height of the walls; b) at the height of the pillar and the vault

The tests of the mass moisture content $U_{m}$ across the thickness $d$ of one of the outer walls of the ground floor, which were carried out at two heights above the ground level and the results of which are shown in Figure 4, showed that at a height of $10 \mathrm{~cm}$ above the ground level the wall was very damp to about half of its thickness (from the interior of the room), while from the exterior of the building it has acceptable humidity. This indicates a small effect of the lateral capillary action on the moisture content of the partition. In turn, 
the results of tests carried out at a height of $40 \mathrm{~cm}$ above the ground level proved that the wall has an acceptable moisture content of around $3.0 \%$ on its entire thickness. This condition is illustrated in Figure 4.

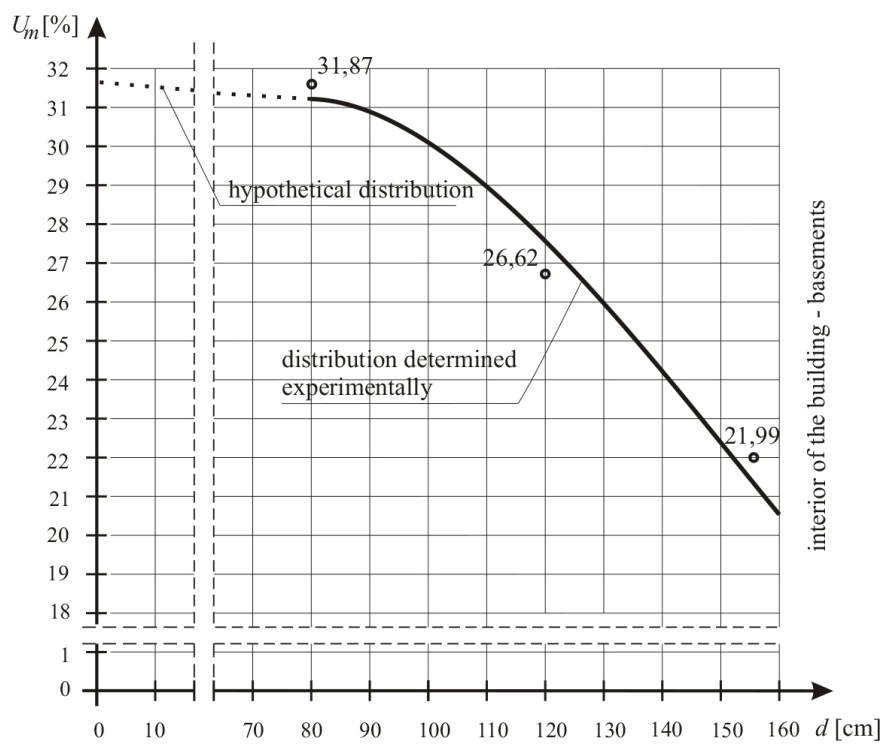

Fig. 3. The distribution of the mass moisture content $U_{m}$ across the thickness of the brick external wall at the underground level

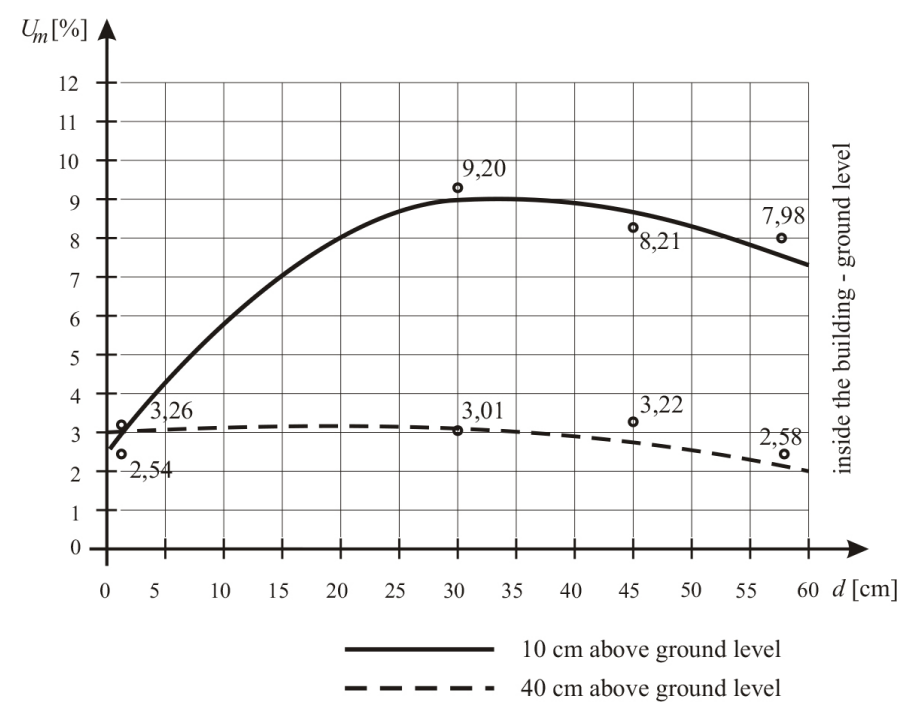

Fig. 4. The distribution of the mass moisture content $U_{m}$ across the thickness of the brick external wall at the ground level

In addition, qualitative and semi-quantitative studies regarding the type and concentration of salts were carried out. They showed that there are harmful salts in the form of chlorides and sulphates in the basement walls, refectory and cloisters. However, 
the case of chlorides and sulphates, is small.

The physical features of the ceramic bricks from which the basement walls were made were determined experimentally. It was established that their total porosity is very high and amounts to almost 34\%. By adding this result to the high mass moisture content of the wall both in the subsurface zone and in the middle of its thickness, it should be noted that the degree of filling the wall's pores with water is very high and, depending on the considered wall zone, ranges from about $62.0 \%$ to about $93.0 \%$. This information is of great importance when selecting a method of anti-moisture protection of underground walls.

Summing up, after analysing the obtained test results and analysing the information resulting from the organoleptic assessment, the main reason for excessive moisture of the brick walls of the monastery's basements was the free capillary action of the ground water due to a lack of horizontal damp insulation. This process is compounded by the evaporation of moisture from wet walls and the floor, which with the absence of effective ventilation of the rooms causes the secondary moistening of these partitions with moisture contained in the air. The dampness of the walls is also caused by the lateral capillary action of water from the ground through a wall, which is caused by the lack of vertical damp insulation. However, as concluded on the basis of the conducted tests, it has a smaller impact on the moisture state of the underground brick walls than the capillary action from below the ground level.

\section{Formulated recommendations}

In order to protect the building's basements from the inflow of moisture, and also to dry the building's partitions and improve the thermal and humidity conditions of its interiors, it was recommended to deprive the free capillary action of water from the ground of the internal and external walls and floors by the execution of horizontal and vertical damp-proof insulations. For this purpose, removal of the existing floor layers in a larger basement room was recommended, followed by the making of new floors in both basement rooms. Horizontal damp-proof insulation in these floors was recommended to be made of polymerbituminous mass or micro-mortar that seals the joints with a horizontal damp-proof membrane made in the walls.

Due to the high degree of filling the pores in a wall with water, it was recommended to create a horizontal damp-proof membrane in the external and internal walls of the basements. This membrane should be in the form of a two-stage pressure insulation located just above the planned floor level. In the first stage, capillary absorption should be performed, which consists of inserting cement suspension into the injection holes drilled in the wall. This will fill cavities, such as caverns or empty joints. However, in the second stage it was recommended to perform a proper injection with an agent based on a silicon microemulsion.

Vertical insulation of the exposable external walls was recommended to be made as coatings that are made of a sealing micro-mortar or modified polymeric bituminous mass (Fig. 5). In turn, it was recommended to execute the vertical insulations of the external walls, which cannot be uncovered, as a curtain made of fast-binding two-component acrylic gel. For this purpose, special steel lances should be used with a length that allows the wall insulation to a depth below the level of the horizontal diaphragm to be made. At first, the existing brick floors should be removed in the rooms that are adjacent to the walls being insulated. Afterwards, the above-mentioned lances need to be entered into the ground in the close vicinity of the walls with a spacing of approximately $30 \mathrm{~cm}$. The gel should be implemented in stages from the bottom up, while lifting the lance by approximately $30 \mathrm{~cm}$ in each stage. After the vertical insulation of the walls is done, these floors will be re- 
arranged on the previously made concrete substrate, which was insulated with a polymerbituminous mass (Fig. 6). This treatment will significantly improve both the moisture state of the building's partitions in the ground level and the comfort of using the basement rooms.

After carrying out the proposed damp-proof protection, drying of the excessively moistened walls using the microwave method and horn generators was recommended.

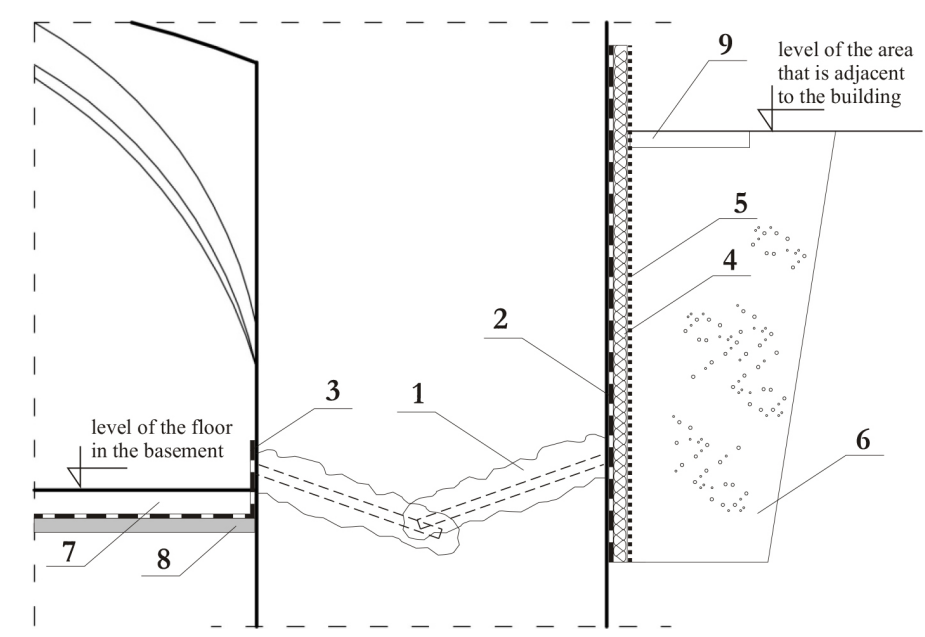

Fig. 5. Scheme of the proposed method of anti-damp protection of the underground walls, the excavation of which is possible: 1 - horizontal membrane made to a height of up to $10 \mathrm{~cm}$ above the floor level on both sides using the two-stage pressure injection, 2 - vertical damp-proof insulation of a moderate type made of a mineral micro-mortar or modified polymer-bituminous mass up to a height of about $30 \mathrm{~cm}$ above the ground level, 3 - horizontal sub-floor insulation made of micro-mortar or polymer-bituminous mass that reaches the wall to the height of the injection holes, 4 - extruded polystyrene, 5 - polystyrene board cover made of bubble foil, 6 - excavation filled with filter backfill, 7 - new cement or brick floor, 8 - concrete substrate under the floor, 9 - $30 \mathrm{~cm}$ wide band next to the wall e.g. made of single-fraction gravel

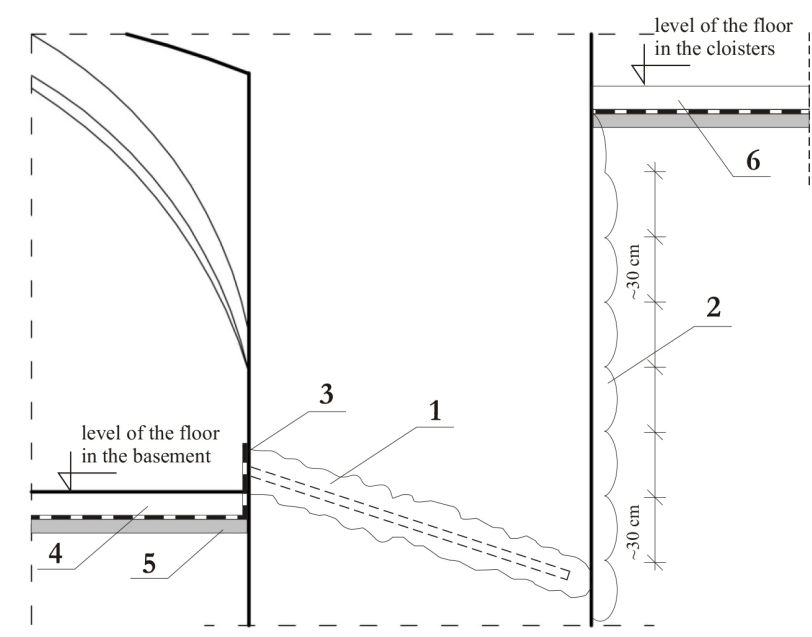

Fig. 6. Scheme of the proposed method of anti-damp protection of the underground walls, the excavation of which is impossible: 1 - horizontal membrane made to a height of about $10 \mathrm{~cm}$ above the floor level using the two-stage pressure injection which is only applied from the room side, 2 - vertical damp-proof curtain insulation made of quick-hardening acrylic gel using the pressure 
injection method, 3 - horizontal sub-floor insulation made of micro-mortar or polymer bitumen mass that leads out to a wall to height of the injection holes, 4 - new brick or cement floor, 5 - concrete substrate under the floor, 6 - existing brick floor, which is previously disassembled and then rearranged on a concrete substrate that is insulated with a polymer-bituminous mass

\section{Summary}

The conducted non-destructive and destructive tests of the mass moisture content of the brick walls in the medieval monastery built at the turn of the thirteenth and fourteenth centuries in Pomerania in Poland showed that in the subsurface zone the brick walls are wet on their entire height, and their moisture content exceeds $12.0 \%$. In the zone adjacent to the floor it amounts to $21.0 \%$, and at the height of $190 \mathrm{~cm}$ over the floor it amounts to over $15.0 \%$. The conducted research also shows that the mass moisture content of a wall across its thickness is higher than that found in the subsurface zone.

Research of the mass moisture content of the walls of the rooms located directly above the basement showed that in the zone that is adjacent to the floor, the tested walls qualify to be very damp due to their mass moisture content ranging from $8.0 \%$ to $12.0 \%$. In the higher parts, however, they have an acceptable humidity of about $3.0 \%$, while the level of the moisture content is higher in the walls from the side of the interior of the rooms than from the outside of the building.

It is important that in the case of the assessed object the correlative dependency between the $X$ indications of the dielectric meter used in the tests and the mass moisture content of the tested walls, which is described by the exponential mathematical function, was determined. The dependence included in this article can be successfully used in the future for the non-destructive assessment of the moisture content of brick walls in other medieval buildings.

The main reason for the excessive moistening of the brick walls of the monastery's basements was the capillary rising of water from the ground through the walls and floor due to the lack of horizontal damp insulation and the subsequent moistening of these barriers with moisture from the air. It was also found that the lateral capillary action of water from the ground has little effect on the moisture status of the walls.

The conducted moisture content tests were used to develop recommendations that can be useful in determining the scope of renovation and construction works that aim at restoring the utilitarian function of the building's underground. This includes, first and foremost, the development of methods of executing vertical and horizontal damp proof insulations of walls. The knowledge contained in this article may be useful in relation to other medieval objects that require repair works.

\section{References}

1. A. Alsabry, Dynamika podciagania kapilarnego $w$ murach budowlanych. Przegląd Budowlany 9, 46-48 (2010)

2. J. Kubik, Przeptyw wilgoci $w$ materiałach budowlanych (Oficyna Wydawnicza Politechniki Opolskiej, Opole, 2000)

3. M. Raimondo, M. Dondi, G. Guardini, F. Mazzanti, Predicting the initial rate of water absorption in clay brick. Construction and Building Materials 23, 2623-2630 (2009)

4. J. Adamowski, J. Hoła, Z. Matkowski, Probleme und Lösungen beim Feuchtigkeitsschutz des Mauerwerks von Baudenkmälern am Beispiel zweier grosser Barockbauten in Wroctaw, Bautechnik, 82, 426-433 (2005) 
5. M. Rokiel, Hydroizolacje $w$ budownictwie. Wybrane zagadnienia $w$ praktyce (Dom Wydawniczy MEDIUM, Warszawa, 2009)

6. A. Hoła, Z. Matkowski, J. Hoła, Analysis of the moisture content of masonry walls in historical buildings using the basement of a medieval town hall as an example, Procedia Engineering 172, 363-368 (2017)

7. H. Domańska, Żarnowiec - zarys historii wsi i opactwa (Zrzeszenie Kaszubsko Pomorskie Oddział w Wejherowie, Wejherowo, 1985)

8. J. Hoła, Z. Matkowski, Wybrane problemy dotyczace zabezpieczeń przeciwwilgociowych ścian w istniejacych obiektach murowanych, Awarie budowlane: zapobieganie, diagnostyka, naprawy, rekonstrukcje. XXIV Konferencja naukowotechniczna, Szczecin-Międzyzdroje, 73-92 (Wydawnictwo Uczelniane Zachodniopomorskiego Uniwersytetu Technologicznego, 2009)

9. A. Goetzke-Pala, Badania wilgotności zasolonej cegły ceramicznej nieniszczaca metoda dielektryczna, Materiały Budowlane 6, 60-62 (2013)

10. A. Goetzke-Pala, J. Hoła, Influence of burnt clay brick salinity on moisture content evaluated by non-destructive electric methods, Archives of Civil and Mechanical Engineering 16, 101-111 (2016)

11. Gentillini C., Franzoni E., Brandini S., Nobile L. Effect of salt crystallization on the shear behavior of masonry walls. An experimental study. Construction and Building Materials 37, 181-189 (2012)

12. CSN P 73 0610. Waterproofing of buildings - The rehabilitation of damp masonry and additional protection of buildings against ground moisture and against atmospheric water - The basic provision (2000)

13. A. Hoła, Measuring of the moisture content in brick walls of historical buildings the overview of methods, IOP Conf. Ser.: Mater. Sci. Eng. 251, 012067 (2017)

14. WTA 2-6-99-D. Erganzungen zum WTA-Merkblatt 2-2-91-D. Sanierputzsysteme (1991) 